\title{
Women, Law, Court and Justice in India (1970 to 2016)
}

\author{
Harneet Kaur \\ PhD, Assistant Professor, Department of History, Guru Nanak Dev University, Amritsar, India \\ harneetjakhar@gmail.com
}

\begin{abstract}
In the personal sphere, the Indian women are facing various issues related to marriage, divorce, inheritance, guardianship, adoption and succession as they are the subjects of personal law, which varies from religion to religion and is attached to an individual at birth and applied to the person wherever she goes. After independence in the 1970s the government first time felt the need to review the ongoing women specific laws and their impact on the status of the women in India. This paper attempts to review the efforts made by the government in this direction. The paper is divided into three sections. The first section covers the legal obstructions for women justice. Second section dealt with the significant recommendations made by the two 'High Level committee on the Status of Women in India' (1974 and 2015) to improve the status of women in India. In the last section analysis were made on the basis of the statistical data of the women's trials and to review the status of the justice delivered to women's in the Indian Courts. The gap between the passing of laws and its implementation by the State needs to be examined, as mere passing of laws cannot transform the lives of women in society. The optimal use of laws can only be judged by the reportage of crimes under various acts and the punishments given to convicts under them.
\end{abstract}

KEYWORDS: Women, Indian Law, Justice, and Status of Women

\section{Introduction}

In India, Justice in relation to marriage, divorce, inheritance, guardianship, adoption and succession imparted according to the personal law of the individual, which varies from religion to religion. This is not a new phenomenon of an independent India even in the times of colonial rule same system of different personal laws was applicable on personal sphere of the individuals. After India's independence on $15^{\text {th }}$ August 1947, it was only in the 1970s the Government of India felt the need to review the ongoing women specific laws and their impact on the status of the women in India. The change and continuity in the women's life was the concern of the Government as it was already a journey of 23 years of the independent India. To review the status of women in India the Government of India formed first committee in 1971 and then second in the year of 2013 only.

The first two sections of the paper highlight the certain legal inequalities of the laws towards the women justice and recommendation to remove these legal inequalities for women justice. The second section specifically focuses on the recommendations made by the committee on the status of women in India in the year of 1974 and 2015 respectively (Ministry of Education and Social Welfare 1974; Ministry of Women and Child Development 2015). Till 1970's no comprehensive review of the women specific laws had been undertaken. Some laws were passed from time to time to raise the status of Indian women and embodied the principles underlying by the Indian constitution - As the Preamble to the Constitution of India promises 'to secure to all its citizens, Justice-Social, economic and political; Liberty of thought, expression, belief, faith and worship, Equality of status and oppourtunity; and to promote among them all (Preamble The Constitution of India 1949).

To review the status of women, the Government of India constituted the committee on the Status of women by a resolution of the Ministry of Education and Social Welfare on $22^{\text {nd }}$ September, 1971 to get useful guidelines for the formulation of social policies (Ministry of Education and Social Welfare 1974, xii). The main objective of the Committee was to examine the Constitutional legal and administrative provisions that have a bearing on the social status of women, their education and employment. The committee submitted its report on $31^{\text {st }}$ December 1974 , by clearly saying that 'Our 
investigation has revealed that large masses of women in this country have remained unaffected by the rights guaranteed to them by the Constitution and the laws enacted since independence. Our recommendations are made primarily with view to making these rights more real and meaningful' (Ministry of Education and Social Welfare 1974, Preface). In relation to women specific laws the report of 1974 dedicated the chapter IV, 'Women and the Law' to highlights the legal inequalities towards the women of India. This chapter broadly discussed issues of Polygamy, Age of Marriage, Dowry, Divorce, Adoption, Guardianship, Maintenance and Inheritance. The committee recommends the various changes those were required in the laws to strengthen the women's position in legal terms.

The committee report of 1974 entitled, Towards Equality A Report of the Committee on the Status of Women in India, not only highlights the unequal provisions of the women specific laws it also suggests their solutions. First, the committee highlights the diverse personal laws in relation to bigamy or polygamy, those weaken the position of women in many folds in India. The Committee (1974) was of the view that the continuation of such diverse personal Laws of the Hindus, Muslims, Parsee and Christians are contradictory to our social policy and totally unjustified. As the Muslims personal law supports polygamy. The committee recommends the immediate replacement of these laws by the Hindu Marriage Act of 1955. On the issue of bigamy, the Committee (1974) recommends a clause to be added to Section 5 or in the Section 11 of the Hindu Marriage Act (Ministry of Education and Social Welfare 1974, 111).

Further the Committee (1974) recommends that the Section 16 should also be amended to include all children born outside wedlock and not only children of void and voidable marriage. Further, the term "illegitimate" should not be used in any statute or document. The offence of bigamy may be punished with imprisonment up to seven years and a fine. This indicates the seriousness of the offence. But limiting the right of initiating prosecution to only the aggrieved person, in our social context, defeats the purpose of the law. To remedy, the Committee recommends permitting any person to initiating prosecution for bigamy with the permission of the court.

In relation to child marriage, the Committee (1974) recommends that all offences under the Child Marriage Restraint Act of 1929 should be made cognizable and special officers appointed to enforce the law. With this they also recommend legislation prohibiting courts from granting any relief in respect of a marriage solemnized in violation of the age requirements prescribed by law unless both the parties have completed the age of 18 years (Ministry of Education and Social Welfare 1974, 114). On the Dowry Prohibition Act of 1961 the committee had been pointed out that one of the 'major loopholes' in the existing legislation is that anything is allowed in the name of gifts and presents. Therefore, any gifts made to the bridegroom or his parents in excess of Rs. 500/- or which can be so used as to reduce his own financial liability should be made punishable.

On the issue of the divorce the Committee (1974) reviews the tendency and the role of the judiciary. Instead of the guiding the conflicting parties towards a rational adjustment to the process of social change, the judiciary has either evaded the issue or thrown its weight on the side of the traditional view of the husband's authority. Further on the issue of divorce, the Committee recommends that a definition of 'cruelty' under the Hindu Marriage Act and other Laws must be introduced in order to ensure that it is not completely left to the interpretation of the courts. A provision must be added to the definition of cruelty stating that patriarchal notions of a wife's behavior will not constitute cruelty (Ministry of Education and Social Welfare 1974, 201). Unlike divorce by mutual consent, one party's wish to dissolve the marriage, coupled with a long period of separation, is enough to deem a marriage 'irretrievably broken' where reconciliation is impossible.' The Committee (1974) also recommended that no religion converted person can, for a period of two years at least, be able to affect any marital rights by resorting to the new religion. The merit of deterring people from easy conversion to solve their matrimonial problems, in our opinion conversion should not be a ground for divorce as it offers an easy way of evading matrimonial obligation (Ministry of Education and Social Welfare 1974, 123). 
People in India escape the punishment of bigamy by just converting their religion to Muslim. As bigamy is allowed among the Muslim community, this deteriorated the condition of the women in India.

The Committee of 1974 made general observations in relation to the guardianship rights. The contemporary legislation of various countries has shifted to regarding the child's interest as of prime consideration and parental rights as being subordinate to it. But unfortunately our law does not clearly reflect this trend. The Committee (1974) recommends in relation to various laws elated to women maintenance claims. As the right of the maintenance was given in the personal laws the Criminal Procedure Code, enacted in 1898. The right of the wife and dependent children to move the Court for relief against the husband or the father who neglects or refuses to maintain his dependent family members is thus not confined to any particular religion but is given to all wives and children irrespective of their personal laws.

To this extent uniformity had been achieved in at least one aspect of family law (Ministry of Education and Social Welfare 1974, 128). This code has, however, been repealed and we are today governed by the New Criminal Procedure Code of 1974. In spite of the passage of 76 years, however, the new Code continues to reflect the old attitude to women. At last in relation to inheritance the Committee (1974) highlights the one major factor which has contributed to continuing the inequality between sons and daughters is the retention of the Mitakshara coparcenary. It is confined only to male members. One primary principle of Muslim law which grossly discriminates against women is that under the law of inheritance, if there are male heirs and female heirs of the same degree like a son and daughter, full brother and a full sister, the share of a female member is half that of the male (Ministry of Education and Social Welfare 1974, 139). In regard to guardianship, adoption and inheritance women should be dealt on par with men. On analysis, the Committee of 1974 has found that 'Personal Laws' contain several provisions that are discriminatory towards women and amongst women of different religions. Law has to be dynamic and should keep pace with the changes in social, cultural, economic and political arena. In order for an egalitarian system to prevail, the Legislature must ensure that the law acts as a catalyst in achieving the ultimate objective of a welfare state.

In 2013, the Government of India (Ministry for Women and Child Development 2015, XV), based on the recommendation of the committee of Governors constituted by the President of India, set up a High Level Committee on the Status of Women in India on $24^{\text {th }}$ May 2013. The main objective of the committee was to undertake a comprehensive study on the status of women since 1989 as well as to evolve appropriate policy interventions based on a contemporary assessment of women's needs. The high level committee of 2015 recommends amendments according to present scenario of living.

The summary of the report of 2015 in regard to legal aspect showed that it discusses and recommends all the required amendments in women specific laws in India. The Committee recommends that the provision relating to restitution of conjugal rights under various statutes should be deleted. Again in 2015 repeated recommendation of Committee of 1974 was placed for the definition of word cruelty under Hindu Marriage Act of 1955. The same issue of the irretrievable breakdown of marriage highlighted and demanded that it should not be made a ground for divorce as recommended in 1974. As husband could get a divorcee on the ground of adultery, the wife had to prove an additional ground of cruelty or desertion as well which is quite discriminatory on the part of women should be amended. Both the spouses should be treated equally in relation to adultery charges.

On the issue of adultery, in a historic verdict the Supreme Court on $27^{\text {th }}$ September 2018 declared unconstitutional Section 497 of the Indian Penal Code, which punished only men for having sexual relationship with a married woman. The Court said the law on adultery violated a woman's sexual autonomy and deprived her of dignity. In a unanimous verdict, a five-judge constitution Bench headed by Chief Justice of India Dipak Misra said the archaic Victorian-era law violated a woman's right to equality and right to non-discrimination guaranteed under Article 14 and 15 as it treated women 
as chattel. The Bench, however said adultery can be used as a ground for divorcee by a husband or a wife in matrimonial proceedings. While declaring the penal provision, Chief Justice of India Deepak Misra cautioned that the verdict should not be taken as a license to indulge in such acts (Parkash 2018). The Supreme Court of India scrapped the colonial-era anti-adultery law that punished the offence with jail time and was considered unconstitutional and discriminatory against women. It was the second legal decision of September 2018 reflected the liberal approach of the apex Court. The top Court had earlier decriminalized the controversial Section 377-a 158 year old draconian law on consensual gay sex (Times Now News 2018). The National Commission for Women, Chairperson Rekha Sharma on hailed the Supreme Court's Verdict Section 497 (adultery) and said, 'we are finally thinking on lines of equality' (Sharma 2018). The country has now started with a new way. There were many laws in which women had no equality but finally we are thinking on equal terms.

In matters related to 'divorce' under Section 9 of Hindu Marriage Act of 1956 is discussed by the Committee of 2015. As it has only been post 1975 that Courts began to look into aspects of a woman having a right to hold her job in case it requires her from being away from her husband. (In the case of N. R. Radhakrishna V. Dhanalakshmi the Madras High Court stated that under the modern law the concept of the wife's obedience to her husband and her duty to live under his roof under all circumstances does not apply. Similarly in the case of SwarajGarg V. R. M. Garg the Delhi High Court providing Constitutional validity to the wife's right to hold a job ruled that an exclusive right to the husband to decide on the matrimonial home would be violate of the equality clause under Article 14 of the Constitution - Ministry of Women and Child Development 2015, 199).

The objective of Section 9 was to preserve the institution of marriage but is now being misused. Further restitution of conjugal rights is against human rights of a person as no one can be or should be forced to live with any other person. The Committee (2015) recommends that the provision relating to restitution of conjugal rights under various statutes (Section 9 of the Hindu Marriage Act, Section 22 of the Special Marriage Act, Section 32 of the Divorce Act and others) should be deleted. It should no longer be available as a matrimonial remedy Ministry of Women and Child Development 2015,200). The Committee (2015) has strong point of view that women do have equal right to work and restitution of conjugal right cannot be forced over women alone. Right to work of wife at far off place from husband should not be treated as matter relating to restitution of conjugal right and base for divorce petition.

On the Special Marriage Act of 1954 the Committee (2015) recommends the following changes, Section 6 of the Special Marriage Act requires the marriage officers to be put up every notice of intended marriage at some conspicuous place in his office. It is recommended that notices should not be displayed on the notice board outside the Registrar's office as it places young people, desirous of contracting marriages of choice, at great risk. At present the notice period prescribed under Section 5 is 30 days, this must be reduced to 7 days so that it is conducive for people registering their marriages under it. This is necessary because this provision serves no purpose, except delay the process and a couple wanting to marry in a hurry because of parental or other disapproval cannot afford to wait for a full month. Under Section 4, the age for performance of marriage is 18 for the girls and 21 for the boys, however under Section 15 the age for registration of marriage is 21 years for both the spouses. This provision needs to be clarified.

The special provision made for two Hindus marrying under the Act should be deleted (Section 21A read as follows "Special provision in certain cases-Where the marriage is solemnized under this Act of any person who professes the Hindu, Buddhist, Sikh or Jain religion with a person who professes the Hindu, Buddhist, Sikh or Jain religion, Section 19 and Section 21 shall not apply and so much of Section 20 as creates a disability shall also not apply). Thus, for everyone who marries under the Special Marriage Act, succession would be governed by the Indian Succession Act. This exception for Hindus should be deleted (Ministry for Women and Child 
Development 2015,208). The provision like 30 days waiting or notice period and minimum age of 21 years for both the spouses for the registration of marriage should needs amendment. As both the provisions are only delaying the process of registration of marriage and put pressure on the young couples, nothing else.

Another in relation to the registration of marriages the Committee (2015) recommends that a Central enactment for registration of marriages should be passed which is applicable to all religious groups. In regard to the 'Age of Marriage' the Committee (2015) recommends to bring uniformity in laws. There is a strict need to ensure the proper implementation of the Prohibition of Child Marriage Act of 2006. In the $205^{\text {th }}$ report on the Prohibition of Child Marriage Act, the $18^{\text {th }}$ Law commission had recommended that the minimum age of marriage for both girls and boys should be the same i.e. 18 years. This should be adhered to. This is also in tandem with the recommendations of various international bodies like the UNICEF which points out the discrimination inherent in a provision which stipulates a lower age of marriage of the girl. The Prohibition of Child Marriage Act, 2006 must hold all child marriages voidable and not void (Ministry for Women and Child Development 2015, 209). The age gap between the girl and boy for marriage sometimes becomes evidence that even the state want that girl should be younger to boy. It becomes hard for the couples to get married in which girl in elder than boy. So there is a need of hour to remove this sort of discrimination at legal level.

Further in relation to divorce repeated recommendation (same in 1974 Committee Report) was placed to reduce the period of two years prescribed for mutual consent divorce under the Divorce Act, 1869 should be amended to one year. The scope of Foreign Marriage Act should be enlarged to give relief to more women married abroad. In relation to guardianship both parents should treated at par and equally considered as naturally guardian of their children's. In maintenance claims states should wave off the court fees and has to make its decisions time bound to relief the women in distress. At last the Committee (2015) recommends that any property or rehabilitated property given by state should be registered on the name of both spouses. Still there is repetition of recommendation in relation to conjugal rights and irretrievable breakdown of marriage both should not be dealt as ground of divorce in 2015. But still legal inequalities for the women are not fading away except the relief given to Muslim women by the Supreme Court in the matter of triple talaq as it is declared unconstitutional. Further adultery is no more a criminal offence in India, it can be a ground of divorce. Some of these recommendations are also suggested by the Committee of 1974, still there are repetitive recommendations in the Committee report of 2015, specifically in relation to conjugal rights, definition of cruelty and irretrievable breakdown of marriage. But still certain legal inequalities for the women are not fading away except the relief given to Muslim women by the Supreme Court in the matter of triple talaq (divorce) as it is declared unconstitutional. Further adultery is no more a criminal offence in India, it can be a ground of divorce.

The third section of the paper covers the judicial procedure and Court disposal of the crime against women to get idea how justice is imparted to women in distress in India in five years from 2012 to 2016. Because to review the women cases and justice imparted in the Courts further clarifies the relevance of the women specific laws. This section covers that how many women are approaching Courts in order to get justice under various laws? How many women's are getting justice from the Courts? How many cases in total came before the Courts for disposal and how many sent for the trial each year from 2012 to 2016. In how many cases trial was completed each year and how many went to pendency percentage. After independence there is a series of constitutional guarantees, laws, policies and commissions formed by the Indian government to analysis and uplift the situation and position of the women at all spheres of the life. Still, women vulnerability towards crimes not only exists but show continues increase in the crime rate against 
the women putting questions over the efforts made by the government to make India a safe place for the women. To analyze the effectiveness of the constitutional provisions and laws this section focuses on the Court disposal of crime against women by analyzing total number of cases for trial and the women cases sent for trial during the year. How many cases in which trials were completed and cases pendency percentage left for next year.

The Court disposal of crime against women is discussed crime head-wise from 2012 to 2016. The highest number of cases came before the Court under crime head of 'Cruelty by Husband or his Relatives' with total of 24,96,759 cases followed by crime of 'Assault on Women with Intent to Outrage her Modesty' with 13,03,645 cases, 'Rape' cases 6,30,882 and crime of 'Kidnapping \& Abduction' 6,28,012 cases from 2012 to 2016. The lowest number of total cases came under crime head of 'Domestic Violence' with 2,529 cases followed by 'Indecent Representation of Women' cases of 5,057 and attempt to rape crime of 21916 cases from 2012 to 2016. The crime head of 'Cruelty by Husband or his Relatives' showed tremendous increase of $1,42,763$ cases from 2012 (426922) to 2016 (569685) before the Court. Further the crime of 'Assault on Women with Intent to Outrage her Modesty' showed an increase of 1,21,541 cases and followed by 51124 increase in the 'Rape' cases from 2012 to 2016. The crime head of Kidnapping \& Abduction $(+19223)$, Dowry Deaths $(+19662)$ and Dowry Prohibition $(+13661)$ also showed increase in the number of cases from 2012 to 2016 . There were two crime heads Immoral Traffic ($3430)$ and Indecent Representation of women (-369) showed declining trend in court cases from 2012 to 2016. (See Table-1, Crime-1). This showed that except Immoral Traffic and Indecent Representation of women all other crime heads showed significant increase in the court cases. The highest percentage of 2,29,138 71, 638 cases sent for trial. This clearly shows that even half of the cases didn't go for trial in the Indian Courts which increase pendency percentage each year that is why justice is always delayed. (See Table-1, Crime -2) This showed that the Indian Courts are over burdened even they don't have enough judges to even hear the trial of the registered cases once a year.

The crime head of cruelty by husband or his relatives had highest number of cases $16,03,758$ those came before the court for disposal and only in 2,29,138 cases trials were completed from 2014 to 2016. Under crime of assault on women with 'Intent to Outrage her Modesty' 8,72,255 cases were put before the courts for disposal only in 1,49,498 cases trials were completed, in rape cases $4,15,056$ were put before and in only 88,515 cases in which trials were completed from 2014 to 2016. The number of cases in which trials were completed clearly indicated that as even less than half of the cases went for trials and only 10 percent to 15 percent cases under trials were completed each year. This showed that the Courts only imparting justice or disposing 10 percent to 15 percent women cases each year.

This further clarified if cases pendency percentage analyzed. In 2016, highest cases pendency percentage registered in the cases of 'Domestic Violence' with 94.0 percent, followed by 'Indecent Representation' 92.2 percent, 'Kidnapping \& Abduction' 91.4 percent, 'Dowry Prohibition' 91.2 percent, 'Cruelty by Husband or his Relatives' 90.6 percent and 'Immoral Traffic' 90.1 percent. These crime heads pendency percentages showed that there were only 10 percent cases in which trials were completed and more than 90 percent people still in pipe line to get justice. If the lowest pendency percentage is taken into consideration that was 86.5 percent of crime head of 'Insult to the Modesty of Women' followed by 'Rape' cases pendency 87.7 percent and 'Assault on Women with Intent to Outage Her Modesty' 88.8 percent. 
Table 1. Court Disposal of Crime against Women Cases at National Level

\begin{tabular}{|l|l|l|l|l|l|l|l|l|l|}
\hline Year & 2012 & 2013 & 2014 & 2015 & 2016 & Tota* \\
\hline Crime & 1 & 1 & 1 & 2 & 1 & 2 & 1 & 2 & \\
\hline $\begin{array}{l}\text { Cruelty by } \\
\text { Husband or } \\
\text { his relatives }\end{array}$ & 426922 & 466079 & 499642 & 97081 & 534431 & 90971 & 569685 & 91810 & $24,96,759$ \\
\hline $\begin{array}{l}\text { Assault on } \\
\text { Women with } \\
\text { intent to } \\
\text { outrage her } \\
\text { modesty }\end{array}$ & 201501 & 229829 & 258104 & 66462 & 291109 & 66887 & 323042 & 71638 & $13,03,585$ \\
\hline Rape & 101041 & 114785 & 125433 & 30840 & 137458 & 30001 & 152165 & 33628 & $6,30,882$ \\
\hline $\begin{array}{l}\text { Kidnapping } \\
\text { \& Abduction }\end{array}$ & 120708 & 134287 & 109035 & 26044 & 124051 & 27206 & 139931 & 29084 & $6,28,012$ \\
\hline $\begin{array}{l}\text { Dowry } \\
\text { Deaths }\end{array}$ & 24461 & 38901 & 40477 & 7653 & 42410 & 7150 & 44123 & 7067 & $1,90,372$ \\
\hline $\begin{array}{l}\text { Dowry } \\
\text { Prohibition }\end{array}$ & 24461 & 28073 & 31741 & 9007 & 33586 & 7162 & 38122 & 8455 & $1,78,452$ \\
\hline $\begin{array}{l}\text { Immoral } \\
\text { Traffic }\end{array}$ & 12325 & 12949 & 6614 & 1881 & 7772 & 2122 & 8895 & 1921 & $1,55,983$ \\
\hline $\begin{array}{l}\text { Insult to the } \\
\text { Modesty of } \\
\text { Women }\end{array}$ & 33034 & 35696 & 36734 & 8144 & 36221 & 7019 & 36767 & 6336 & 48,555 \\
\hline $\begin{array}{l}\text { Abetment of } \\
\text { Suicide }\end{array}$ & - & - & 9151 & 2403 & 11319 & 3190 & 13823 & 3872 & 34,293 \\
\hline $\begin{array}{l}\text { Attempt to } \\
\text { Rape }\end{array}$ & - & - & 4806 & 2781 & 6940 & 3174 & 10170 & 4290 & 21,916 \\
\hline $\begin{array}{l}\text { Indecent } \\
\text { Representati } \\
\text { on }\end{array}$ & 1128 & 1348 & 980 & 4 & 842 & 32 & 759 & 54 & 5,057 \\
\hline $\begin{array}{l}\text { Domestic } \\
\text { Violence }\end{array}$ & - & - & 481 & 312 & 846 & 418 & 1202 & 403 & 2,529 \\
\hline
\end{tabular}

*Total-Total Number of Cases for trial during the year (Crime-1). Table 4.13, p.363, 2012 , Table 4.9, 363, 2013. Table 5.6, 2014. Table 5.6, 1-2, 2015. Table 3A.7, 1-20, 2016 (Ministry of Home Affairs, Government of India. 20122016).

Crime 1 - Total Number of Cases for Trial During the Year Crime 2 - Cases Sent for Trial During the year

The cases lowest pendency percentage indicates more than 85 percent cases pendency. This showed that pendency percentage is increasing each year. As in 2014, highest pendency is of 88.8 percent under crime head of abetment to suicide and domestic violence (See Table-2).

More than 85 percent cases always went to pendency and half of them never went under trial every year; showed that justice is given to 15 percent only and more than half of the people just have to wait for years for a trial. By imparting justice to less than 15 percent per year is not a good mark over Indian judicial system. Slow and long procedures of Indian courts are weakening women's faith over judiciary. 
Table 2. Women Cases in which Trials were completed at National level

\begin{tabular}{|l|l|l|l|l|l|l|l|l|l|}
\hline Year & 2012 & 2013 & 2014 & \multicolumn{2}{l|}{2015} & \multicolumn{2}{l|}{2016} & Total \\
\hline Crime & 1 & 1 & 1 & $2(\%)$ & 1 & $2(\%)$ & 1 & $2(\%)$ & \\
\hline $\begin{array}{l}\text { Cruelty by } \\
\text { Husband or his } \\
\text { relatives }\end{array}$ & 46054 & 45423 & 46853 & 88.4 & 46127 & 89.3 & 44681 & 80.6 & $2,29,138$ \\
\hline $\begin{array}{l}\text { Assault on } \\
\text { Women with } \\
\text { intent to outrage } \\
\text { her modesty }\end{array}$ & 25319 & 27528 & 29995 & 86.6 & 34541 & 86.3 & 32115 & 88.8 & $1,49,498$ \\
\hline Rape & 14717 & 18833 & 17649 & 85.7 & 18764 & 86.2 & 18552 & 87.7 & 88,515 \\
\hline $\begin{array}{l}\text { Kidnapping \& } \\
\text { Abduction }\end{array}$ & 14830 & 15988 & 11791 & 88.7 & 12879 & 89.2 & 11720 & 91.4 & 67,208 \\
\hline $\begin{array}{l}\text { Insult to the } \\
\text { Modesty of } \\
\text { Women }\end{array}$ & 6956 & 6604 & 5778 & 79.3 & 3998 & 84.0 & 3629 & 86.5 & 26,965 \\
\hline Dowry Deaths & 5216 & 5284 & 5061 & 87.1 & 5165 & 87.4 & 4351 & 90.0 & 25,077 \\
\hline $\begin{array}{l}\text { Dowry } \\
\text { Prohibition }\end{array}$ & 4225 & 4205 & 4617 & 83.1 & 3212 & 88.3 & 3233 & 91.2 & 19,492 \\
\hline Immoral Traffic & 1817 & 1632 & 949 & 85.6 & 987 & 87.2 & 854 & 90.1 & 6,239 \\
\hline $\begin{array}{l}\text { Abetment of } \\
\text { Suicide }\end{array}$ & - & - & 1014 & 88.8 & 1340 & 87.2 & 854 & 90.1 & 3,877 \\
\hline Attempt to Rape & - & - & 1016 & 78.2 & 1035 & 84.8 & 1093 & 89.1 & 3,144 \\
\hline $\begin{array}{l}\text { Indecent } \\
\text { Representation }\end{array}$ & 131 & 342 & 169 & 82.7 & 137 & 83.6 & 59 & 92.2 & 838 \\
\hline $\begin{array}{l}\text { Domestic } \\
\text { Violence }\end{array}$ & - & - & 47 & 88.8 & 46 & 94.3 & 69 & 94.0 & 162 \\
\hline
\end{tabular}

*Total-Cases in which Trials were completed (Crime-1). Table 4.13, 363, 2012. Table 4.9, 363, 2013. Table 5.6, 2014. Table 5.6, 1-2, 2015. Table 3A.7, 1-20, 2016. (Ministry of Home Affairs, Government of India. 2012-2016).

Crime 1 - Cases in which Trials were completed.

Crime 2 - Cases Pendency Percentage.

\section{Conclusion}

The analysis of the two committee's reports of 1974 and 2015 on the status of women in India showed that there are certain legal inequalities are present like bigamy or polygamy among the Muslims, the committee suggests the replacement of these laws with by the Hindu Marriage Act of 1955 or uniform civil code. Both the committees' recommends defining the 'cruelty' word and putting stop on the usage of the term "illegitimate" in any statute or document. The Committee (1974) recommends that all offences under the Child Marriage Restraint Act of 1929 should be made cognizable and special officers appointed to enforce the law. Unlike divorce by mutual consent, one party's wish to dissolve the marriage, coupled with a long period of separation, is enough to deem a marriage 'irretrievably broken' where reconciliation is impossible. The Committee (1974) also recommended that no religion 
converted person can, for a period of two years at least, be able to affect any marital rights by resorting to the new religion. The committee's recommends reducing the period of two years prescribed for mutual consent divorce under the Divorce Act, 1869 should be amended to one year. The provisions like 30 days notice period and minimum age of 21 years for both the spouses for the registration of marriage should be amended to 7 days and same age of both the spouse should be introduced. In relation to inheritance the Committee of 1974 highlights the one major factor which has contributed to continuing the certain inequality between sons and daughters is the retention of the Mitakshara coparcenary. At last the Committee (2015) recommends that any property or rehabilitated property given by state should be registered on the name of both spouses. The Committee (2015) recommends that the provision relating to restitution of conjugal rights under various statutes should be deleted. Both committees repetitively recommend various suggestions to remove certain legal inequalities in relation to women. Till 2018, two major judgments in relation to triple talaq (divorce) and adultery came. The women are facing certain legal obstacles in personal sphere to get justice from the Courts. The third section further clarifies that if women went to the Courts to get justice, it is only 10 to 15 percent women those are getting justice annually. The pendency percentage of cases was more than 85 percent. The victims always have less patience and survival strengthen. Further, it was very hard for Indian women to fight such long cases as they always needs family support to continue their judicial fight. She was always accompanied by her family, relatives and friend to the Court proceedings. So in present times nobody has such time to go to the Courts years after year for justice. Even long and tedious judicial procedure also lessens the chances of women resettlement or rehabilitation specifically if she wants to remarry. The certain legal inequalities and slow procedure of the justice makes the women approach to justice hard in India but they do get justice.

\section{References}

Ministry of Education and Social Welfare, Government of India. December 1974. Towards Equality A Report of the Committee on the Status of Women in India.

Ministry of Home Affairs, Government of India. 2012-2016. "Crime in India." National Crime Record Bureau. Available at http://ncrb.gov.in/.

Ministry of Women and Child Development, Government of India. June 2015. Report of the High Level Committee on the Status of Women in India.

Parkash, Satya. 2018. "Adultery not a crime, rules top court." The Tribune, September 28. Available at https://epaper.tribuneindia.com/1834055/The-Tribune/TT-28-September-2018\#page/3/2.

Sharma, Rekha. 2018. "Adultery law Verdict: Finally we are thinking on lines of equality." September 27. Available at https://economictimes.indiatimes.com/news/et-tv/adultery-law-verdict-finally-we-are-thinking-on-lines-of-equalitysays-ncw-chief/videoshow/65977838.cms?from=mdr.

The Constitution of India. "Preamble." https://www.india.gov.in/sites/upload_files/npi/files/coi_part_full.pdf.

Times Now News. 2018. "Adultery not a crime in India anymore: A quick glance at other countries where it still is." September 27. https:/www.timesnownews.com/india/article/adultery-supreme-court-india-adultery-verdict-adulterylaw-china-united-states-pakistan-philippines-zia-ul-haq-iran-saudi-arabia-sudan-europe-zina/291040. 